\title{
A Note on the Toxicity of a Chinaman Fish*1
}

\author{
Yoshiro Hashimoto*2, Hisao KamiYA ${ }^{* 2}$, Kiei Kinjo*3, and Chokei YoshidA ${ }^{* 3}$ \\ (Received May 14, 1975)
}

An outbreak of food poisoning with 25 patients occurred from the ingestion of a chinaman fish Glabrilutjanus nematophorus in Okinawa Island in 1974. The symptoms recorded, such as diarrhea, chill, fatigue, joint-ache and dry-ice sensation, were very close to those of ciguatera. The toxicity of the flesh recovered from the fish dealer was tested on cats and mice, in which the effects were very close to those induced by ciguatoxin.

The toxic principle was partially purified by column chromatography using silicic acid and DEAE-cellulose. The toxicity was checked by a mouse test. The toxin was eluted with chloroform-metanol (9:1) from a silicic acid column. By subsequent DEAE-cellulose column chromatography, two toxic components were obtained; the one was eluted with chloroform and the other with chloroform-methanol $(1: 1)$. The major toxin eluted with chloroformmethanol $(1: 1)$ was not distinguishable from ciguatoxin by either thin layer chromatography or effects in mice, while the minor toxin eluted with chloroform was clearly different from ciguatoxin.

An outbreak of food poisoning occurred from the ingestion of a chinaman fish Glabrilutjanus nematophorus at Gushikawa in Okinawa Island on May 10, 1974. According to the survey made by the Ishikawa Health Center, the fish was consumed by a total of 50 persons as "Sashimi" and soup. Twenty-five persons of 11 families were affected and developed symptoms very close to those of ciguatera, consisting of diarrhea, nausea, chill, fatigue, langour, joint-ache, numbness of extremities, and dry-ice sensation. It took more than a week to recover completely and even a month in severe cases. There was no death.

Fortunately we obtained a fillet and head of the toxic fish recovered from the fish dealer, and could demonstrate the presence of ciguatoxin and an unidentified fat soluble toxin in the flesh. The present paper deals with the results of toxicity test and some chemical properties of the toxin.

\section{Materials and Methods}

A fillet and head of the causative fish recovered by the Ishikawa Health Center were used as specimens. The fish weighed about $15 \mathrm{~kg}$ and was landed at fish market in Naha on May 9, 1974. The fishing ground was unknown. The fish was identified as "Itofukifuedai" Glabrilutjanus nematophorus by Mr. S. Inoha, Okinawa Prefectural Fisheries Ex-

*1 Studies on Marine Toxins.---.--XILIX.

*2 Laboratory of Marine Biochemistry, Faculty of Agriculture, The University of Tokyo, Tokyo, Japan (啝本若郎・神谷久男: 東京大学串学部)

*3 Okinawa Prefectural Institute of Public Health, Naha, Okinawa Prefecture, Japan（金城喜栄 - 吉田 朝警：沖維鼠感害衛生研究所) 
perimental Station, who examined the head of the fish. It is locally called "Inubâ" in the Ryukyus. The specimens were stored in a freezer at $-20^{\circ} \mathrm{C}$ until used.

The toxicity was tested by using cats and mice as test animals. In a cat assay, each $50 \mathrm{~g}$ of raw flesh was fed to cats weighing 1 and $1.5 \mathrm{~kg}$ at first. The water soluble and fat soluble fractions were then prepared from the flesh by our routine method for ciguateric fishes, ${ }^{1}$ mixed well with a small portion of canned mackerel, and fed to cats each weighing $0.5 \mathrm{~kg}$ at a level of $10 \%$ body weight on the basis of raw flesh.

In a mouse test, the fat soluble fraction was injected intraperitoneally into mice weighing about $20 \mathrm{~g}$ after being emulsified with $1 \%$ Tween 60 in physiological saline. The serial dilutions of the sample were assayed and the minimum dose that killed mice within $48 \mathrm{hr}$ was sought. Two mice were used for each dilution. The toxicity was expressed in $\mu \mathrm{g}$ per $\mathrm{g}$ of mouse.

By using mice as test animals, the toxic principle was partially purified for characterization as follows. The fat soluble fraction prepared from $100 \mathrm{~g}$ of the muscle was fractionated on a column $(30 \mathrm{~g}, 2 \times 21 \mathrm{~cm})$ of silicic acid (Mallinckrodt, $100 \mathrm{mesh})$ with chloroform, chloroform-methanol $(9: 1)$, chloroform-methanol $(1: 1)$ and methanol, in order. The toxic eluate was then applied to a column $(2 \times 8 \mathrm{~cm})$ of DEAE-cellulose (Brown, acetate form) and eluted in sequence with chloroform, chloroform-methanol $(1: 1)$ and methanol.

In thin layer chromatography, silica gel $\mathrm{H}$ (Merck) combined with chloroformmethanol-acetic acid-water (90:9.5: 0.2:0.3) was used. A portion of toxin was applied to a layer $(0.5 \mathrm{~mm}$ thick, $20 \times 20 \mathrm{~cm})$ and developed to a height of $10 \mathrm{~cm}$. The plates were then divided into several bands by monitoring with fluorescence under ultraviolet light. Each band was scraped off and extracted with chloroform containing $20 \%$ methanol. After removal of solvent, the extract was emulsified with Tween 60 in physiological saline and injected into mice.

\section{Results}

Signs of laboratory animals A cat weighing $1.5 \mathrm{~kg}$ fed $50 \mathrm{~g}$ of raw flesh revealed paralysis in hind limbs $17 \mathrm{hr}$ after and in four limbs $30 \mathrm{hr}$ after administration. The cat fell into a coma that continued for 2 weeks. Thereafter, the animal recovered gradually and started to walk within 3 weeks. Neither vomiting nor diarrhea was recognized in the observation period. A cat weighing $1 \mathrm{~kg}$ fed the same amount of raw flesh showed paralysis of limbs, prostration, coma and death after 2 weeks. The fat soluble fraction prepared from $50 \mathrm{~g}$ of the flesh caused paralysis, coma and death 7 days after administration in a cat weighing $0.5 \mathrm{~kg}$. While the water soluble fraction induced no signs in another cat of the same weight.

In mice the fat soluble fraction caused loss of activity, severe diarrhea, dyspnea and death, but lacrymation and salivation were not recognized. The death time ranged from 
6 to $20 \mathrm{hr}$ depending on dose.

Partial purification and chemical properties of the toxins The fat solible fraction (solids $640 \mathrm{mg}$, toxicity $840 \mu \mathrm{g} / \mathrm{g}$ ) from the muscle was fractionated by silicic acid column chromatography. The eluate $(67 \mathrm{mg})$ with chloroform-methanol $(9: 1)$ was toxic at a level of $250 \mu \mathrm{g} / \mathrm{g}$, and the other eluates were nontoxic at a level of $1,000 \mu \mathrm{g} / \mathrm{g}$. By subsequent DEAE-cellulose column chromatography, two toxic components were obtained; the one was eluted with chloroform $(28 \mathrm{mg}, 350 \mu \mathrm{g} / \mathrm{g})$ and the other with chloroform-methanol $(1: 1)(24 \mathrm{mg}, 160 \mu \mathrm{g} / \mathrm{g})$. In thin layer chromatography, the component appearing in the chloroform fraction gave the toxic band at Rf $0.4-0.7$ on silica gel $\mathrm{H}$ plates. The signs in mice were labored breathing, abnormality in walking, paralysis in hind limbs and death, differing from those induced by ciguatoxin. The component found in the chloroformmethanol (1:1) fraction gave the toxic band at $0.1-0.4$ in thin layer chromatography under the same conditions. The signs in mice were similar to those induced by ciguatoxin.

\section{Discussion}

A chinaman fish is reputed to become poisonous occasionally. Several outbreaks of food poisoning due to this species were recorded in Australia, ${ }^{2}$ but none in the Ryukyus. ${ }^{3 \text { ) }}$ We confirmed the presence of ciguatoxin in the toxic flesh which caused human illness in the Ryukyus. Signs in cats and mice were very close to those induced by ciguatoxin. These results indicate that this fish is classified as ciguateric.

In addition to ciguatoxin, we detected an unknown fat soluble toxin in the flesh, that evoked paralysis in hind limbs and dyspnea in mice. The toxin, however, seemed to be far less important than ciguatoxin in this fish. Further study was impossible due to the limited availability of the specimen. In the previous paper, ${ }^{4}$ we reported that a surgeonfish Ctenochaetus striatus from Tahiti bears a secondary toxin in addition to ciguatoxin. It is of interest that a chinaman fish from the Ryukyus also has the secondary toxin in the flesh.

\section{Acknowledgement}

The authors are indebted to Mr. S. Inoha, Okinawa Prefectural Fisheries Experimental Station, for identification of the specimen, to Messrs. K. Taira and S. Kudaka, the Ishikawa Health Center, for supply of specimens, and to the staff of the Ishikawa Health Center, for support in field investigation.

\section{References}

1) Y. Hashimoto, T. Yasumoto, H. Kamiya, and T. Yoshida: This Bull., 35 (3), 327-332 (1969).

2) B. W. Halstead: Poisonous and Venomus Marine Animals of the World, Vol. 2, U. S. Government Printing Office. Washington D. C. (1967).

3) Y. Hashimoto, S. Konosu, T. Yasumoto, and H. KamiYa: This Bull., 35 (3), 316-326 (1969).

4) T. Yasumoto, Y. Hashimoto, R. Bagnis, J. E. Randall, and A. H. Banner: ibid., 37 (8), 724 733 (1971). 